\title{
Dress, Desire, and Displacement in Góngora’s Sonnets
}

\author{
ELIZABETH AMANN
}

Ghent University

Ces dernières années, les études critiques ont souligné le rôle du regard - le plaisir de la vue - dans la représentation du désir chez Góngora. Cet article met lemphase sur le rôle d'intermédiaire du désir dans la poésie de Góngora. L'analyse se penche sur un groupe de sonnets qui représentent diverses robes, "Oh piadosa pared, merecedora » (1582), "Culto Jurado, si mi bella dama » (1583), et « Del color noble que a la piel vellosa" (1584). À l'aide d'une lecture attentive, on y examine comment le désir dans ces poèmes est déplacé du corps de l'aimé vers un tiers, intermédiaire, qui est associé à l'esthétique. Dans ces trois cas, la relation entre le sujet qui regarde et l'intermédiaire prend le pas sur la relation entre ce sujet et l'objet du désir. Les poèmes mettent en lumière l'importance du phantasme et de la perception esthétique dans le concept du désir chez Góngora.

$\mathrm{A}_{\text {sight and desire in the poetry of Luis de Góngora (1561-1627). In his }}^{\text {number of recent studies have drawn attention to the connection between }}$ classic essay "Barthes, Góngora and Non-Sense," for example, Paul Julian Smith points to the visual pleasure of the wrestling scene in Las Soledades, in which "the display of male bodies is offered explicitly for the gaze of women." And in another insightful article, Mary E. Barnard examines the scopophilia in the Fábula de Polifemo y Galatea. This emphasis has helped to distance Góngora's work from conventional views of love. As Smith observes, Góngora inverts the standard gender scenario of the male viewer and the female object of vision, and Barnard stresses Góngora's rejection of the Neoplatonic model: the sight of the beloved does not induce a "Neoplatonic surge toward heaven" but rather an earthly desire. ${ }^{2}$ It is important, however, to recognize that the path from eyes to eroticism is neither immediate nor unmediated. This essay will probe the indirect nature of fantasy in Góngora, the complex ways in which desire is triangulated, transposed, and mediated in his poetry. 
The analysis that follows will focus on three sonnets, which, on the surface, are very different from one another. One describes a wall with a chink that allows a lover to see his beloved; another encourages a friend to sing the praise of a beautiful lady; and the third describes a woman who wears a tawny, leonine dress. All three sonnets, however, share a number of features which shed light on Góngora's vision of desire. In all of them, we are led to expect a visual pleasure: the revelation of the beauty of the beloved. Instead of unveiling a body, however, Góngora represents a form of dress, which ultimately supplants the beloved as the focus of attention. In all three cases, the initial, simple scenario-that of a subject/lover longing for an object/beloved-is superceded by a relationship between the subject and a "third," whose connection exists not at the level of the natural or the physical but rather in the sphere of fantasy and aesthetics.

\section{1. “Oh piadosa pared, merecedora” (1582)}

In the first sonnet, "O piadosa pared, merecedora," the lyric voice addresses a wall that separates him from his lady:

Oh piadosa pared, merecedora

de que el tiempo os reserve de sus daños,

pues sois tela do justan mis engaños

con el fiero desdén de mi señora ${ }^{3}$

[Oh merciful wall, worthy

of being spared from the ravages of time

because you are the divide where my illusions joust

with the fierce disdain of my lady].

Góngora's sonnet belongs to the classical tradition of the paraklausithyron, the song sung by the rejected suitor outside the house of the beloved. In the most famous examples of the genre-Catullus 67; Horace, Odes 3.10; Tibullus 1.2, Ovid, Amores 1.6 and Propertius 1.16-the implacability of the lady is projected onto her wall or door, which prevents the lover from entering the house. The disappointed suitor blames, berates, and even threatens the barrier, hoping to gain admission. ${ }^{4}$ Góngora's poem clearly enters into dialogue with this tradition but is unusual in its calm tone and complimentary treatment of the wall. 
This aberration raises several questions: Why does the lover praise the wall? And what does he want from it?

In the opening quatrain, Góngora sets up an opposition: a metaphorical joust between the lover's illusions and his lady's disdain. The wall functions as the "tela," a chivalric term referring to the barrier that keeps the horses from colliding in a tournament. The wall, thus, has a curious and somewhat contradictory function: on the one hand, it is a site where these combatants "justan" (joust) - a place that facilitates their encounter-but, on the other, it is a separator that prevents their contact. The lyric voice praises the wall not just as a vehicle of communication or vision - a space for trysts or voyeurism - but also as a distancing mechanism. In the standard paraklausithyron, the lover wishes to cross the divide, to penetrate the abode and presumably the body of the beloved. Góngora's version, in contrast, seems to value the wall's function as a separator. The "piadosa pared" allows for the fantasy but prevents the head-on collision of illusion and disdain, an encounter that could only result in disillusionment.

The second stanza of the sonnet shifts from a chivalric to a sartorial image:

cubra esas nobles faltas desde ahora, no estofa humilde de flamencos paños (do el tiempo puede más), sino, en mil años, verde tapiz de yedra vividora [May these noble faults henceforth be covered not by the humble stuff of Flemish cloth (which time can outdo) but rather, for a thousand years, by a green tapestry of living ivy.]

The opposition in these verses-the distinction between lowly Flemish fabric and a more lasting covering of living ivy-mirrors that of the first quatrain. The coarse cloth of Flanders corresponds to the bitter reality of the lady's indifference-"el fiero desdén de mi señora"-while the living tapestry echoes the lover's illusions- "mis engaños"-which persist just as the ivy withstands the ravages of time. This opposition is not only temporal but also stylistic: the asceticism and pragmatism associated with Flemish realism contrast with the lavish ivy, which is described as a tapestry, a purely aesthetic object. Just as the 
lyric voice seeks to protect his amorous illusions from the reality of the lady's disdain, so he prefers the metaphorical weaving (ivy as tapestry) to real cloth. The chiastic structure of verses 6 and 8 reinforces this aesthetic opposition. In the description of the Flemish fabric, the adjectives are surrounded by "sustantivos" (nouns), smothered by substance (Flemish stuff): "estofa humilde de flamencos paños." In contrast, the adjectives-verbal ornamentation-envelop the objects in the description of the ivy: "verde tapiz de yedra vividora." Just as the poet seeks to dress the wall in a beautiful ivy tapestry, he privileges an aesthetic that dresses reality in embellishing adornments (adjectives), an art that modifies (in all senses) the reality that it describes.

As we move from the octave to the sestet, it becomes clear that the praise and well-wishing of the lyric voice are not disinterested:

y vos, aunque pequeño, fiel resquicio

(porque del carro del cruel destino

no pendan mis amores por trofeos),

ya que secreto, sedme más propicio

que aquel que fue en la gran ciudad de Nino

barco de vistas, puente de deseos. (126)

[And you, faithful, though small, chink

(so that my loves do not hang as trophies

from the chariot of cruel destiny)

be more propitious to me, since you are secret,

than the one that was in the great city of Ninus

a boat of vision, a bridge of desire.]

The sonnet, we now discover, takes the form of an exchange: the lyric voice rewards the wall with the prospect of a beautiful dress (an ivy tapestry) in the hope that it will look favourably on his cause. Notably, these verses address not the wall but its absence: its hole. This shift from dressed to bare wall, from the obstacle to the crack, leads us to expect a revelation, a glimpse of what lies beyond. The poem, however, disappoints these expectations. After the brief mention of "mi señora" in verse 4, the lady never reappears in the poem. Rather than reveal her beauty, the sestet alludes to a Classical myth: the story of the Babylonian couple, Pyramus and Thisbe, to which Góngora would dedicate one of his longer poems (Fábula de Píramo y Tisbe, 1618). Pyramus and Thisbe, whose 
parents oppose their union, speak to one another through a chink in the wall separating their estates. Eventually, the two lovers decide to elope and plan to meet at the tomb of Ninus, but when Thisbe arrives a lion threatens her, and she runs away leaving behind her mantle. The beast tears apart the garment and in the process stains it with the blood of earlier victims. When Pyramus discovers the blood-spattered shawl, he assumes that Thisbe is dead and commits suicide. Shortly thereafter, Thisbe returns to the scene, discovers Pyramus's corpse, and takes her own life. ${ }^{5}$

The sad fate of the Babylonian couple echoes the dire outcome feared in the parenthetical clause of verses 10 and 11: the image of the carriage of destiny carrying off the lover's sentiment as a trophy. But though the image in the first tercet and the myth in the second are both tragic, the emphasis in the former lies on the cruel triumph of reality, of destiny, while the focus of the latter is the fantasy conjured up by the wall: "barco de vistas, puente de deseos." Once again, the poet returns to the distinction between reality and illusion. The first tercet echoes the disdain and the Flemish cloth of the octave, while the second recalls the "engaños" and ivy tapestry. Although Pyramus and Thisbe's love ends tragically, the lyric voice imagines that his own story will be more propitious because the chink in the wall is hidden: "ya que secreto." It is not the site of a real tryst but a place where an encounter can be imagined. Indeed, the description in the final verse seems to apply more to the lover's situation than to that of Pyramus and Thisbe. Where the wall was for the Babylonian couple a means of communication and exchange, it is for the "yo" a source of visual pleasure, of non-reciprocal fantasy.

This concluding image returns to the contradictory logic of the joust in the first quatrain. As we have seen, "tela" seems to work in contrary ways, permitting an encounter between opposing lances but also keeping them at a safe distance. The description of the chink as both boat and bridge echoes this situation, for a boat moves in a direction perpendicular to a bridge. A boat does not cross the bridge but rather passes under it. Once again, the poet seems to celebrate the wall as both a facilitator and an obstacle to his desire. We might expect the line to read "puente de vistas, barco de deseos": it would be more natural to identify desire with the vehicle, a moving object that advances toward its goal, passing beyond the bridge of vision. But Góngora inverts the terms: the lover's glances pass under the eroticizing bridge of desire. The wall, 
that is, is not a means or vehicle so much as a filter that fosters and perhaps creates the erotic aura that surrounds the beloved. It is the mediator of this desire.

The structure of the poem takes the form of a striptease: it shifts from the dressed to the bare, from the wall-separator to the chink and all that it might reveal to the lover. But the chronology of the sonnet moves in an opposite direction: it is because the undressed wall has been propitious and supplied his fantasy that the lover wishes that it may be clothed in verdant tapestry. In the end, the poet seeks to clothe precisely the "nobles faltas" (noble faults) that he appreciates for allowing him to see. The wall, that is, may begin as a window, a transparent representation of reality, but it ultimately will serve as a page, a canvas for the tapestry that the lover imagines woven upon it. The initial description of the wall as a "tela," which also means cloth, anticipates its eventual function as a textile-text. When the ivy covers the holes and the wall ceases to reveal something beyond itself, it will become a non-referential text, an aesthetic object in its own right. ${ }^{6}$ Pyramus's error is to assume a referential relation between Thisbe's bloody mantle and reality, to read signs as a reflection of the world. Góngora's poem, in contrast, privileges a form of art that renounces the real and the realization of desire. The dress in this poem-the "tela" and the ivy tapestry-ultimately supplants the beloved and the body as the object of praise and desire. What the poet privileges here is not the beloved but the aestheticizing perspective through which she is seen, a perspective that eventually becomes independent of the reality beyond it, that becomes a source of beauty in and of itself. The relationship between the poet and the wall-the third in this poem-ultimately takes precedence over the erotic scenario of the paraklausithyron.

\section{2. “Culto Jurado, si mi bella dama” (1583)}

Just as the wall in "O piadosa pared" becomes a figure for an aesthetic ideal, the third in "Culto Jurado, si mi bella dama" is an artist: Góngora’s friend and fellow poet, Juan Rufo. In the opening lines of the sonnet, the lyric voice asks Rufo, who was also a judge ("jurado") in Córdoba, to sing the beauty of his beloved:

Culto Jurado, si mi bella dama,

-en cuyo generoso mortal manto

arde, como en cristal de templo santo, 
de un limpio amor la más ilustre llamatu Musa inspira, vivirá tu fama sin invidiar tu noble patria a Manto, y ornarte ha, en premio de tu dulce canto, no de verde laurel caduca rama, sino de estrellas inmortal corona. [Learned Judge, if my beautiful lady -in whose generous mortal mantle burns, as in the glass of a sacred temple, the most illustrious flame of a pure loveinspires your Muse, your fame will live on without your noble homeland envying Mantus, and you will be adorned, as a reward for your sweet song, not with the withered branch of a green laurel but with an immortal crown of stars.]

As in "O piadosa pared," the lady in question more or less disappears after verse 4: the only description of her in the poem appears in the parenthetical aside of lines 2-4. The rest of the sonnet focuses on the beauty of the poem that will describe her and on the fame that will accrue to its author.

As with the wall in "O piadosa pared," the poet's reward takes a wearable form: a crown. And once again, the lyric voice distinguishes between two materials, one flimsier than the other. Just as the living ivy is preferable to coarse Flemish cloth, so the immortal crown of stars outlasts and outshines the laurel wreath. By rejecting the laurel, the tree associated with Petrarch's beloved Laura, Góngora establishes Rufo as the Italian poet's equal or superior. But the laurel is not the only garment rejected in these verses. The echoing between "manto" (mantle) in verse 2 and "Manto" (the founder of Mantua) in verse 6 suggests that Rufo has outdone not only the laurel of Petrarch but also the mantle of Virgil, the poet of Mantua. Having surpassed both the Italian and the Latin bards, Rufo merits a celestial adornment: a crown of stars.

The opening lines of the poem describe a series of containers: the mortal mantle (i.e. the beloved's body) contains the flame of a pure love, just as the crystal glass in a temple contains a sacred offering. Rufo's composition presumably will also contain the lady, representing her beauty. Structurally, however, the cup runneth over: Góngora’s clauses spill over strophic divides that ordi- 
narily would contain them. It would seem more natural for "tu Musa inspira" (inspires your Muse) to be placed in the first quatrain, but the protasis runs into the second. Verses 8 and 9, which describe the two possible rewards, not only have a parallel structure (de + material [laurel/estrellas] + noun [ rama/ corona]) but also form a chiasmus (adjective [verde], noun [laurel], noun [estrellas], adjective [inmortal]). Nevertheless, the two lines are separated by the volta, traditionally a breaking point in a sonnet. Through this structural overflowing, Góngora suggests that Rufo's poem will go beyond what it contains or represents.

Indeed, it is interesting to observe that Góngora describes Rufo's work not in terms of its content-its representation of an external reality (the lady) — but rather in terms of its effect. The logic of the poem is causal. Its first nine lines are an if-then statement that describes the effects of the poem on its author: his everlasting fame. And the final five verses describe its effect on his audience:

Haga, pues, tu dulcísimo instrumento

bellos efectos, pues la causa es bella;

que no habrá piedra, planta, ni persona,

que suspensa no siga el tierno acento,

siendo tuya la voz, y el canto de ella. (133)

[May your very sweet instrument, therefore, make

beautiful effects, since the cause is beautiful;

for there will be no stone, plant or person

that will not follow, transfixed, the tender accent,

the voice being yours, and the song being hers/its.]

Not only does the sonnet refer explicitly to causes and effects in verse 11 but it also reiterates the word "pues" (therefore), and its final line is introduced by a gerund that is causal in force. Drawing on J. L. Austin's terms, we might say that Góngora evokes Rufo's poem not as cognitive or representational language, language that mirrors the world, but rather as performative language, words that have an effect on reality, that cause change. Notably, it is not the poet who follows (and imitates) Nature but rather Nature-flora, fauna, and even stones-that follows, transfixed, the voice of the poet. The final lines allude to the myth of Orpheus, whose song has a similarly powerful effect, mesmerising the beasts and the rocks and compelling them to follow him. ${ }^{7}$ 
The phrase "bellos efectos, pues la causa es bella" is highly equivocal. It might be tempting to consider the cause to be the beauty of the lady and the effect to be the beauty of the music. ${ }^{8}$ But this interpretation is not consistent with either the octave or the final tercet in both of which the cause is the poet's poetry. In the last stanza, Nature comes to a halt because the voice is his ("siendo tuya la voz"). Similarly in the quatrains, it is because he sings that his fame will endure. Indeed, if we read lines 10 and 11 in the context of the if-then statement that precedes it, it is more logical to interpret "causa" not as "lo que produce el efecto" (that which produces the effect) but rather as a "fin, motivo, razón que concurre para executar ò emprender alguna cosa" (an end, motive, reason for executing or undertaking something). ${ }^{9}$ The lyric voice, that is, encourages the poet to make beautiful effects not because the subject of the poem is beautiful but rather because it is for a beautiful cause, the goal of achieving everlasting glory, an immortal crown of stars.

The final line mirrors verse 11 both in its chiastic structure and ambiguity. For the key to the interpretation of the sonnet is our understanding of the antecedent of its final word: "ella" (hers/its). Does "ella" refer to the beloved or to "la voz" (voice)? Is it because the song is about her that all Nature will be transfixed? ${ }^{10}$ Or is it because the song comes from his voice? Once again, the larger context suggests that the cause is the poet rather than the lady. In verse 7, the sonnet clearly identifies the song with the poet: "en premio de tu canto." Both the instrument ("tu dulcísimo instrumento"; "tuya la voz") and its effects ("tu dulce canto") belong to him. Even if we interpret "ella" as referring to her as the subject of the song, moreover, it is noteworthy that what makes the stones, plants, and people follow him is not the content of his poem but the tone of his voice: "el tierno acento" (the tender accent). The power of the poem, that is, is its formal beauty, not its representation.

The sonnet, thus, sets up an opposition between two views of language and literature: the representational-the idea of the text as a mirror of reality-and the performative-the idea of language as an instrument that has an effect upon the world. In the octave, the lyric voice seems to subscribe to the former view: the lady inspires Rufo's Muse, propelling him to record her beauty in verse. The "cristal" (glass) of verse 3, which could also be translated as "mirror," suggests this ideal of transparency. But the sestet shifts away from this understanding of literature, replacing the Muse with the instrument and concentrating on the effects that his voice will have on nature. The poetry is 
viewed not only as performative language but also as a performance: he is singing before an audience of stones, plants, and people.

In both "O piadosa pared" and "Culto jurado," the third is associated with an aesthetic ideal that transcends the real: a lavish ornamentation that goes beyond the coarse stuff of Flemish realism and a poetry so powerful that it suspends and silences all of Nature. In each case, moreover, the "third," which the poet seeks to reward, seems to displace the object of desire. In theory, Rufo is the mediator of the love between the "yo" (I) and the "bella dama" (beautiful lady), but the poem describes neither the lyric voice's love for her nor her effect on him. In her brief, parenthetical appearance, she is not so much a beloved object as a desiring subject (a flame of love burns in her soul). The focus of the poem is rather the effect of Rufo's poetry on all of Nature, which implicitly includes the lyric voice himself (everyone will be transfixed by his tender accent). The real desire in this poem is that of the lyric voice for Rufo and his verse.

In both "O piadosa pared" and "Culto Jurado," thus, the "third," be it the wall or the poem, becomes an object of desire in its own right. And in each case, it displaces the body of the lady that it serves to reveal or record: the ivy dressing would cover the chink and prevent the revelation of the woman's beauty just as the crowning of Rufo upstages the "mortal manto" (i.e. the body) of the beautiful lady. In both poems, that is, the ornamentation of the third takes precedence over the corporality of the beloved. The aesthetic trumps the real, and in so doing replaces "natural" desire, the love of the lady, with a desire for the aesthetic, for the mediating third, be it the metatextual figure of the wall or Rufo's poetry.

\section{3. "Del color noble que a la piel vellosa" (1584)}

Perhaps the most flamboyant description of clothing in Góngora's sonnets is a 1584 composition that evokes a woman in a leonine dress. The opening lines describe the colour of this garment through a radical hyperbaton:

Del color noble que a la piel vellosa

de aquel animal dio naturaleza, que de corona ciñe su cabeza, rey de las otras, fiera generosa

[In the noble colour, which Nature gave 
to the downy skin of that animal, which girds its head as a crown, King of the others, generous beast.]

In these verses, Góngora resorts to extreme indirection. First, he avoids mentioning the colour of the dress, alluding instead to an animal associated with it. But this periphrasis itself contains a periphrasis, for instead of using the word "león," Góngora evokes the lion's mane and his status as the king of the beasts. The entire quatrain could be summarized in a single word: yellow. But Góngora devotes four lines to this detail. An important question, therefore, is the reason for such indirection and tangled syntax: why does Góngora begin the sonnet with clauses subordinated to clauses subordinated to clauses, with a periphrasis within a periphrasis?

To a certain extent, the befuddled syntax of the first quatrain reflects the general confusion of the observer. In the second stanza, we learn that the lyric voice, seeing the lady in this tawny dress, has mistaken her for one of the wild beasts of Libya:

vestida vi a la bella desdeñosa,

tal, que juzgué, no viendo su belleza,

(según decía el color con su fiereza),

que la engendró la Libia ponzoñosa

[I saw the disdainful beauty dressed,

in such a way that I concluded, not seeing her beauty

(judging by the colour and its fierceness),

that poisonous Libya had engendered her].

The octave suggests that natural and artificial clothes are difficult to tell apart. Not only does the artificial covering (the lady's attire) seem remarkably like the natural (the lion's skin), but Nature's dress also resembles the artificial: the description of the lion's mane (a natural adornment) as a crown (a man-made one) collapses the opposition between art and Nature.

The confusion of the octave leads the reader to form expectations about the sestet. If the quatrains describe a mistake, we might expect the tercets to correct it, to reveal the truth and the woman beneath the dress. The opening words of the sestet-"mas viéndola"-seem to introduce a contrast between 
misleading appearances and bodily reality. This hint at a striptease, however, is but a tease. Instead of disclosing the beauty beneath the garment, the sestet introduces a new character, the mythical figure of Hercules (Alcides):
mas viéndola, que Alcides muy ufano
por ella en tales paños bien podía
mentir su natural, seguir su antojo,
cual ya en Lidia torció con torpe mano
el huso, y presumir que se vestía
del nemeo león el gran despojo. (140)
[But seeing her, that Alcides very proudly
for her in such clothes might well
falsify his nature, follow his/her caprice,
just as in Lydia he once wound with a clumsy hand
the spindle, and presumed that she/he wore
the great spoil of the Nimian lion.]

The sestet begins with an ellipsis: in line 9 Góngora omits the main verb, which the gerund modifies. Ordinarily, the sentence would read "Mas viéndola, pensé que ..." but Góngora has chosen to omit the first-person subject in the sestet. We expect that the "yo," having given his impression of the lady dressed, will now tell how he reacted to the lady undressed, but instead he projects the role of seeing and reacting onto Hercules. His desire for the woman unveiled is thus mediated by the mythical figure.

In this respect, the volta resembles that of "O piadosa pared": both move from an object impeding vision or contact to a potential revelation. Just as the sestet of "O piadosa pared" turns from the blocking wall to a chink that allows an unimpeded view, so these verses move from the lion's skin, which prevents perception, to a male reaction to the woman herself. In neither case, however, does the poet reveal the reality unveiled in the sestet. Rather, each poem veers off into a digression on a classical theme: the story of Pyramus and Thisbe in "O piadosa pared" and of Hercules and Omphale in "Del color noble." Both digressions, moreover, revolve around misleading clothing: just as Pyramus is misled by the blood-stained mantle of Thisbe, so Hercules makes a false assumption about a garment in lines 13 and 14 . 
The exact nature of Hercules' misunderstanding is not altogether clear. Like the sestet of "Culto Jurado," these verses lend themselves to several interpretations. To understand them, one must recall two of Hercules' labours: his victory over the Nimian lion, whose skin became his loincloth, and his visit to Lydia, where he served as the slave and lover of Queen Omphale, for whom he took on traditionally female tasks such as weaving and spinning. ${ }^{11}$ Salcedo Coronel glosses the sestet as follows:

Juzgué, que por tal hermosura, podía Alcides muy ufano disfrazar su natural varonil en aquellos vestidos femeninos. Como en otro tiempo lo hizo en Lidia, torciendo con torpe mano: esto es, hilando indignamente como mujer. [...] Y vistiéndose aquellos feminiles paños, podía presumir que se vestía la piel del león Nemeo, por la semejanza del color y la condición desdeñosa de su dueño. ${ }^{12}$

[I judged that for such beauty, Alcides might very proudly disguise his masculine nature in those feminine clothes. Just as at another time he did so in Lydia, weaving with a clumsy hand: that is, spinning shamefully like a woman. [...] And wearing those womanly clothes, he could presume that he was wearing the skin of the Nimian lion, because of the similarity of colour and the disdainful nature of its owner.]

For Salcedo Coronel, these verses imagine Hercules wearing a woman's dress and mistaking it for his own lion's skin. This reading assumes that the subject of the verb "se vestía" is Alcides, who is also the antecedent of the possessive in "mentir su natural."

This reading, however, is problematic in two ways. First, it would seem more logical for the two possessives in "mentir su natural, seguir su antojo" to have the same antecedent. Although one might imagine that Alcides is falsifying his own nature on his own caprice, the reference to the queen of Lydia suggests a situation of subordination: Alcides is actually following her caprice. If we assume that both possessive pronouns refer to the woman, then Hercules is falsifying her nature and presumes in the final tercet that she is wearing the booty of the Nimian lion, Hercules' usual dress. A second source of confusion is the placement of the phrase "en tales paños." Is it that Hercules is "mintiendo su natural," falsifying his own nature, by wearing "tales paños"? Or is he dazzled by the woman dressed in such garbs ("por ella en tales paños")? In other words, 
we might interpret the sestet as the description of a man cross-dressing as a woman but still thinking that he is a man, taking the leonine dress for a virile loincloth (this is Salcedo Coronel's reading). Or we might read these verses as a description of a man mistakenly believing that a woman has dressed herself in his own loincloth.

Whichever reading we accept, it is clear that Góngora has veered away from a striptease - undressing - and is depicting instead a kinky erotic gamecross-dressing-with overtones of domination and submission. This scenario is, to a certain extent, anticipated in the opening lines. The accumulation of subordinated clauses in the initial quatrain reflects at the level of grammar and form the scene of subordination evoked in the sestet. Verse 4, moreover, anticipates the gender confusion at the end of the poem. We would expect the lion to be "rey de los otros," with "otros" referring to the "animal" of the second verse, but Góngora chooses a more jarring structure in which the pronoun "otras" precedes its antecedent "fieras." The intricacy of the opening serves, on the one hand, to give the reader a taste of the lyric voice's perplexity before this phenomenon and, on the other hand, to hint at the bizarre sexual scenario of the conclusion.

Given the oddity of this final situation, it is not surprising that Salcedo Coronel opts to read the sestet as describing Hercules in the leonine garment. The hero may be wearing a woman's dress but he does so because it is indistinguishable from his usual attire. In the context of the myth itself, however, this reading is somewhat less convincing. In many versions of the story, Omphale and Hercules exchange attire: she wears his loincloth while he sports her dress. Salcedo Coronel's reading, however, softens the shock and incongruity of this exchange: Hercules may wear the woman's clothes, but they are so similar to his own that he does not lose a sense of his masculinity and virile conquests. Hercules is always Hercules whether he wears her lion skin or his own; the underlying Herculicity of Hercules is never threatened. This is not the case, however, with the alternate reading: the idea of Hercules confronting a woman wearing a leonine dress and mistaking it for his own loincloth. Although the cross-dressing here is imagined rather than real (the woman is not wearing Hercules' clothes but rather her own dress), the confusion retains the shock of the transvestism in the myth. The woman seems to be dressed as a man; her clothing is never re-feminized. 
The poem makes a number of allusions that support this reading. In the sestet, the reference to Hercules' domestic tasks- 'torció con torpe mano/ el huso"-echoes a stanza from Tasso's Gerusalemme liberata (XVI, 3) that describes Rinaldo's idleness while in Armida's palace:

Mirasi qui fra le meonie ancelle favoleggiar con le conocchia Alcide.

Se l'inferno espugnò, resse le stelle, or torce il fuso; Amor se 'l guarda, e ride.

Mirasi Iole con la destra imbelle per ischerno trattar l'armi omicide; e indosso ha il cuoio del leon, che sembra ruvido troppo a sí tenere membra. ${ }^{13}$

[Look at Alcides chatting among the Mæonian maidservants. He who conquered Hell and ruled the stars is now winding the spindle; Love looks at him and laughs. Look at Iole handling in jest his deadly arms with her dainty right hand; she who has put on the lion skin, which seems too coarse for such tender limbs.]

While Rinaldo-Alcides spins among the women, Armida-Iole (Renaissance texts often confuse Omphale with Iole) parades about with his club and lion's skin. Once again, it is the woman who dons the Herculean loincloth. In its introduction of a cognitive error about dress into the story of Hercules and Omphale, the sonnet also recalls Book IX of Ovid's Heroides, a letter from Deianira to Hercules in which the cast-off wife complains of his infidelities and mocks him for submitting to the Lydian queen:

o pudor! hirsuti costis exuta leonis

aspera texerunt vellera molle latus!

falleris et nescis-non sunt spolia illa leonis, sed tua, tuque feri victor es, illa tui.

[O shame, that the rough skin stripped from the flanks of the shaggy lion has covered a woman's delicate side! You are mistaken, and know it notthat spoil is not from the lion, but from you; you are victor over the beast, but she over you. $\left.{ }^{14}\right]$ 
Góngora has inverted the mistake in these lines: in the Heroides, the hero fails to recognize himself in the clothing worn by the other (worn by the triumphant Omphale, the loincloth has become the sign of his own defeat, but Hercules doesn't realize it), while in the sonnet he recognizes himself incorrectly in the clothing worn by the other (i.e. he mistakes the lady's loincloth for his own). In Ovid, the loincloth is always the same but is perceived in different ways (as a symbol of the lion's defeat or as a symbol of Hercules' own). The underlying reality is identity; difference is but a matter of interpretation. Góngora, in contrast, describes a disturbing similarity between objects that are fundamentally distinct: his lady is not wearing Alcides' loincloth but rather her own, but the hero finds the two indistinguishable. The sonnet introduces into Ovid's scenario the uncanniness that Deleuze associates with the simulacrum: "a similarity that arises against the background of [a] 'disparité du fond"." ${ }^{15}$ What Delaneira criticizes in Ovid's text is a power structure gone awry: a conqueror (Hercules) conquered by a woman (Omphale). The situation of Góngora's Hercules, however, is even more troubling, for his very identity is threatened. The lion pelt is the hero's trademark; it is what makes Hercules Hercules. But in the face of this simulacrum, he can no longer distinguish it. ${ }^{16}$

If we accept the second reading, in which Hercules believes that the woman is dressed in his clothes, the sestet takes on homoerotic overtones. For what attracts Hercules is not her femininity but rather her fierceness, her simulacrum of his own virility. In this representation, Góngora may be drawing on a baroque tradition of representing Hercules as the lover of men. In artworks such as Pollauiolo's "Hercules and Antaeus" (1448) and Luca Signorelli's drawing "Hercules and Antaeus" (ca. 1500), Hercules wrestles Antæus in such a way that he seems to penetrate him. And in operas from the period, a contralto usually sang the role of the mythical hero. ${ }^{17}$ As Frederick de Armas has shown, Góngora exploits the homoerotic force of the encounter of Hercules and Antæus in the description of a race at the end of the Soledades. The passage draws an analogy between the runners' embracing the elm trees at the finish line, which are described as "hercúleos troncos," and Apollo embracing Daphne as she turns into a laurel tree. The alignment of Hercules with Daphne in this analogy and the description of the Herculean trunks as an object of male embrace correspond to the homoerotic representation of the hero. ${ }^{18}$

Góngora's introduction of the simulacrum into the story of Omphale and Hercules may be a metaphor for the homoerotic situation at which he hints. 
Just as the woman's dress is a simulacrum of nature's covering - the lion's skinand of Hercules' traditional garb, so male-male desire displaces and mimics the "natural" scenario of the love between man and woman. This displacement is clear in the triangulation that Góngora introduces in the sestet. At first the poem seems a conventional lyric poem describing the desire of a male "yo" for a female object, but the digression in the final lines transforms that lady into an alter-Alcides. If we look only at the sestet, it seems that a narcissistic and homoerotic scenario (Alcides-Alcides) has been projected onto a heterosexual relationship (Alcides-Omphale). But if we consider the larger triangle of the poem (the shift from the "yo" of the octave to the Alcides of the sestet), the reverse scenario seems more compelling. If the woman is ultimately a simulacrum of Hercules, then the principal desire in the poem is that of the "yo" for Alcides. It is not Hercules that mediates the lyric voice's desire for the lady but rather the woman who mediates the attraction between the "yo" and the mythical hero.

The three poems examined in this essay traditionally fall under the rubric of "sonetos amorosos." Early on, each one introduces a beautiful lady_ "mi señora," "mi bella dama," "la bella desdeñosa" - who is the object of desire and seems posed to be the centrepiece of the poem. We might assume that the pleasure will reside in the revelation or representation of the beauty of the beloved. In all three sonnets, however, the focus shifts away from this figure and toward a Classical myth-Pyramus and Thisbe, Orpheus, Hercules and Omphale-and a "third," which is associated in some way with dress: the wall with its ivy covering, the poet with his crown of stars, and Alcides with his lion pelt.

These mythical stories and third parties mediate the relationship between the subject and object. The lyric voice sees the beloved through the wall, through Rufo's poetry, or through the eyes of Hercules. In all three cases, moreover, the rapport between the subject and the mediator seems to displace that between the subject and the object of desire. In "O piadosa pared," the wall is praiseworthy in part because it separates the "yo" from his lady, because it substitutes imaginary pleasures - aesthetic fantasy-for real ones. The wall is not a window on reality - a source of representations and revelations-so much as a barrier that stands between the aesthetic and the real and allows the former to thrive unthreatened. In "Culto Jurado," Rufo's poem will be successful not because of its revelation of the beloved but rather because of the beauty of 
his voice and its effect on his audience. What draws listeners to him is not the representational but the performative function of Rufo's poetry, as well as his spellbinding performance. The true focus of the poem is not the attractions of the lady but those of the poet, who in his aesthetic creation, like Orpheus, triumphs over Nature: stones, plants, and people alike will follow his song. Finally, in "Del color noble," the figure of Hercules seems at first a displacement of the "yo": the lyric voice views his beloved through the eyes of the mythical hero. What this perspective reveals, however, is an uncanny mirroring between the hero and the heroine: the woman's garb is a simulacrum of Hercules' lion pelt. What draws the lyric voice to this woman is ultimately her Herculicity. The true magnet here is not the lady in and of herself but her resemblance to the "third."

All of these poems suggest that desire is not a "natural" attraction, a force that spontaneously generates between a subject and an object, but rather a highly mediated affair in which the mediator, the fantasy, or the aesthetic perception of the object often displaces the object itself. The insistence on dress in these sonnets serves to underscore this artificiality and mediation. We perceive the object of our desire through aesthetic and textual veils, which are ultimately more lasting and powerful than the fragile reality that lies beneath. Petrarch's laurel always points to Laura. Góngora’s "de estrellas inmortal corona," in contrast, seems free of such referentiality. In these poems, dress, the text, and the aesthetic displace the real and become the true object of desire.

\section{Notes}

1. Paul Julian Smith, “Barthes, Góngora, and Non-Sense," PMLA 101 (1986), p. 86.

2. Mary E. Barnard, "The Gaze and the Mirror: Vision, Desire, and Identity in Gongora's Fabula de Polifemo y Galatea," Caliope 8 (2002), p. 71.

3. Luis de Góngora, Sonetos completos, ed. Biruté Ciplijauskaité (Madrid: Castalia, 1969), p. 126. Quotations from this work are hereafter cited in the text. All translations in this paper are the author's except where otherwise noted.

4. On the paraklausithyron as a genre, see F. O. Copley's classic study Exclusus Amator: A Study in Latin Love Poetry (Madison, Wisconsin: American Philological Association, 1956) and W. J. Henderson, "The Paraklausithyron Motif in Horace's odes," Acta classica 15 (1973), pp. 51-67. Examples of the convention in Spanish literature of the Golden Age include: Lupercio Leonardo de Argensola’s "Si quiere 
Amor que siga sus antojos," Francisco de Rioja's "Aunque pisaras Fili, la sedienta," Pedro Soto de Rojas's "Noche de invierno en su puerta," and Francisco de Quevedo's "A la puerta de Aminta." On the paraklausithyron in Spanish literature, see Christine Orobitg, "Exclusus amator: en torno a un poema de Quevedo ('A la puerta de Aminta')" in Studia aurea: actas del III congreso de AISO (Pamplona: GRISO, 1996), I, pp. 415-24, and Antonio Ramajo Caño, "Anotaciones clásicas y cristianas a un soneto de Lope ('¿Qué tengo yo que mi amistad procuras?'), Epos 9 (1993), pp. 619-29. Jesús Ponce Cárdenas also discusses echoes of the genre in Góngora’s canción “iQué de invidiosos montes levantados [...]!”. See his Evaporar contempla un fuego helado: género, enunciación lírica y erotismo en una canción gongorina (Málaga: Universidad de Málaga, 2006), pp. 132-42.

5. On the Pyramus and Thisbe myth, see Book 4 of Ovid's Metamorphoses.

6. On the tendency for the aesthetic to supplant the natural in Góngora, see Edward Friedman, "Realities and Poets: Góngora, Cervantes, and the Nature of Art," Calíope 8 (2002), pp. 55-68.

7. See the opening lines of Book 11 of Ovid's Metamorphoses.

8. In her edition of the sonnets, Giulia Poggi adopts this interpretation: "Il ricorso ai concetti scolastici di causa ed effetto ribadisce il ruolo della donna, sublime ispiratrice di una sublime poesia" [The use of scholastic conceits of cause and effect confirms the role of the woman, the sublime inspirer of a sublime poetry]. See Luis de Góngora, I sonneti, ed. Giulia Poggi (Roma: Salerno, 1997), p. 179. Salcedo Coronel seems to support this reading as well: "Haga pues tu dulcísimo instrumento, celebrando la hermosura de mi dama, bellos efectos, pues la causa de que proceden es tan bella" [May your very sweet instrument, therefore, celebrating the beauty of my lady, make beautiful effects, since the cause from which they proceed is so beautiful]. See García Salcedo Coronel, Obras de Don Luis de Góngora (Madrid, 1636), II, p. 441.

9. Diccionario de Autoridades (Madrid: Francisco del Hierro, 1729), p. 236.

10. This is the interpretation of Salcedo Coronel: "siendo la voz de Juan Rufo, y el asunto del canto, la hermosura de su dama" [being the voice Juan Rufo's, and the subject of the song, the beauty of his lady], II, p. 441.

11. The story of Hercules and Omphale appears in the following Classical texts: Sophocles' Trachiniae; Apollodorus' Bibliotheca 2.6.2-3; Propertius 4.9; Ovid's Fasti 2.303-358; and Ovid's Heroides 9. For medieval and Renaissance versions, see Boccaccio's De mulieribus claris XXI (Boccaccio uses the name of Iole instead of Omphale); Torquato Tasso's Gerusalemme liberata, XVI, 3 and VI, 92; and 
Ronsard's poem "Le satyre." For critical discussions of the myth, see Dominique Fernández, A Hidden Love: Art and Homosexuality (Munich: Prestel, 2002); Natalie Kampen, "Omphale and the Instability of Gender," in Sexuality in Ancient Art, ed. N. B. Kampen (Cambridge: Cambridge University Press, 1996), pp. 233-46; Sara H. Lindheim, "Hercules Cross-Dressed, Hercules Undressed: Unmasking the Construction of the Propertian Amator in Elegy 4.9," American Journal of Philology 119 (1998), pp. 43-66; Nicole Loraux, "Herakles: The Super-Male and the Feminine," in Before Sexuality: The Construction of Erotic Experience in the Ancient Greek World, ed. David M. Halperin, John J. Winkler, and Froma Zeitlin (Princeton: Princeton University Press, 1990), pp. 21-52; and Monica Silveira Cyrino, "Heroes in D(u)ress: Transvestism and Power in the Myths of Herakles and Achilles," Arethusa 31 (1998), pp. 207-41.

12. Salcedo Coronel, II, pp. 421-24.

13. Torquato Tasso, Gerusalemme liberata. Tomo primo (Naples, 1835), p. 112, emphasis mine.

14. Ovid, Heroides and Amores, trans. Grant Showerman (London, 1925), pp. 116-17.

15. J. Hillis Miller, Fiction and Repetition: Seven English Novels (Cambridge, Mass.: Harvard University Press, 1982), p. 6. On this uncanny form of repetition, see Gilles Deleuze, Logique du sens (Paris: Minuit, 1971), p. 302.

16. It is also interesting to note that the first line of the poem cites a line from the Aeneid (Book VIII, verse 177) in which Evander invites Aeneas to sit on a lion skin-"uillosi pelle leonis"-in honour of the feast of Hercules. From the outset, the poem hints that the woman is dressed in a Herculean garb.

17. On homoerotic representations of Hercules in the Renaissance, see Fernández, pp. $128 \mathrm{ff}$.

18. Frederick de Armas, "Embracing Hercules/Enjoying Ganymede: The Homoerotics of Humanism in Góngora’s Soledad Primera," Calíope 8 (2002), pp. 137-38. 